\title{
Metabolic endotoxemia: a molecular link between obesity and cardiovascular risk
}

\author{
Ana Luísa Neves', João Coelho', Luciana Couto ${ }^{2}$, Adelino Leite-Moreira' \\ and Roberto Roncon-Albuquerque $\mathbf{J r}^{1}$
}

Departments of ${ }^{1}$ Physiology and Cardiothoracic Surgery ${ }^{2}$ General Practice, Faculty of Medicine, University of Porto, Al. Prof. Hernâni Monteiro; 4200-319 Porto, Portugal
Correspondence should be addressed to R Roncon-Albuquerque Email rra_jr@yahoo.com

\begin{abstract}
Obesity is associated with significantly increased cardiovascular (CV) risk and mortality. Several molecular mechanisms underlying this association have been implied, among which the intestinal barrier has gained a growing interest. In experimental models of obesity, significant alterations in the intestinal barrier lead to increased intestinal permeability, favoring translocation of microbiome-derived lipopolysaccharide to the bloodstream. This has been shown to result in a two- to threefold increase in its serum concentrations, a threshold named 'metabolic endotoxemia' (ME). ME may trigger toll-like receptor 4-mediated inflammatory activation, eliciting a chronic low-grade proinflammatory and pro-oxidative stress status, which may result in high CV risk and target-organ damage. In this review, we discuss the potential molecular implications of ME on several CV risk factors, such as obesity, insulin resistance, dyslipidemia, and oxidative stress, as well as its potential impact on the development of CV target-organ disease.
\end{abstract}

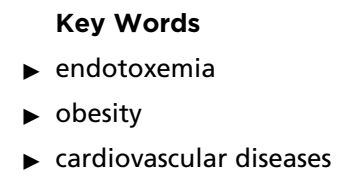

Journal of Molecular Endocrinology (2013) 51, R51-R64

\section{Introduction}

Cardiovascular $(\mathrm{CV})$ diseases remain the leading cause of death in the western world; being estimated, they will be responsible for more than 23 million deaths in 2030 (WHO 2002). Despite the advances made in CV risk factor treatment and control, the incidence of $\mathrm{CV}$ disease has not significantly reduced (Pádua 2002).

Changes in nutritional status in western countries seem to contribute significantly to CV risk and mortality (Otaki 1994, Poirier \& Eckel 2002). Lifestyles and eating habits promote an exponential increase in obesity, which is associated with an array of metabolic complications (dyslipidemia, insulin resistance, and type 2 diabetes mellitus (T2DM)) that foster a significant risk for $\mathrm{CV}$ disease (Poirier \& Eckel 2002).
Obesity is associated with significantly increased CV risk and mortality (Otaki 1994, Poirier \& Eckel 2002, WHO 2002). However, the molecular mechanisms underlying this association remain largely unknown. Several factors have been implied, among which the intestinal barrier has gained a growing interest (Backhed et al. 2004). In experimental models of obesity, significant alterations in the intestinal barrier occur (Cani et al. 2007a). In these models, structural intestinal changes lead to increased intestinal permeability, favoring translocation of microbiome-derived lipopolysaccharide (LPS) to the bloodstream (Pirlich et al. 2006, Cani et al. $2007 a$ ). This results in a two- to threefold increase in its serum concentrations, a threshold named 'metabolic

Published by Bioscientifica Ltd 
endotoxemia' (ME; Cani et al. 2007a). ME may trigger tolllike receptor (TLR) 4-mediated inflammatory activation, eliciting a chronic low-grade proinflammatory and prooxidative stress status associated with obesity, which may result in CV target-organ damage (Suganami et al. 2007, Puppa et al. 2011). ME may thus represent a molecular link between obesity and increased CV risk.

In this context and in a translational perspective, novel questions arise regarding the intricate relationship between metabolism, innate immunity, and global CV risk. A better understanding of the molecular link between the human intestinal microbiome and host's innate and inflammatory responses might thus open the way to innovative therapeutic strategies for CV risk reduction.

\section{Intestinal changes and ME}

In physiological conditions, the intestinal epithelium acts as a continuous barrier to avoid LPS translocation; however, some endogenous or exogenous events may alter this protective function (Cani et al. 2008).

Weight gain has been associated with a higher gut permeability and subsequent systemic exposure to mildly increased LPS circulating levels. Erridge et al. (2007) demonstrated that a high-fat diet promotes LPS absorption across the intestinal barrier, increasing its plasma levels by two to three times, a threshold defined as ME. These data are supported by previous studies that had also found that higher concentrations of fatty acids impair intestinal barrier integrity (Velasquez et al. 1993, Levels et al. 2001).

Two mechanisms of LPS absorption have been proposed. Ghoshal et al. (2009) showed in an in vitro model of human epithelial adenocarcinoma cells that the formation of quilomicron promotes LPS absorption. Other suggested mechanisms include LPS absorption through internalization by intestinal microfold cells (Hathaway \& Kraehenbuhl 2000) and enterocytes, involving TLR4 and myeloid differentiation protein-2 (MD-2; Neal et al. 2006).

Moreover, some bacteria can induce and/or modulate the expression of genes involved in the barrier function in host epithelial cells (Hooper \& Gordon 2001). It has been demonstrated that the introduction of a high-fat diet in mouse models resulted in a decreased expression of genes involved in the barrier function, namely zonula occludens 1 and occludin genes (Cani et al. 2008).

\section{ME and innate immune response}

In order to maintain the delicate relationship of mutualism with the host, intestinal bacteria need to be present above the epithelial surface or within the intestinal mucus, with those penetrating the epithelial barrier having to be immediately eliminated.

How exactly gut distinguishes between pathogens and commensal agents is a question for which the answer remains unclear. One hypothesis is that TLRs are compartmentalized in the basolateral aspects of enterocytes or inside epithelial cells (Hornef et al. 2003). This hypothesis suggests that a deeper bacterial-epithelial contact might be necessary in order to activate the host's innate immune response (Kelly \& Conway 2005).

The starting point for innate immunity activation is the recognition of conserved structures of bacteria, viruses, and fungal components through pattern-recognition receptors (PRRs; Philpott \& Girardin 2004). TLRs are PRRs that recognize microbe-associated molecular patterns (MAMPs; Turnbaugh et al. 2007) such as several bacterial structures of Gram-negative outer membrane (e.g., LPS) and components of Gram-positive cell wall as lipoteichoic acid or peptidoglycan (Philpott \& Girardin 2004). TLRs are transmembrane proteins containing extracellular domains rich in leucine repeat sequences and a cytosolic domain homologous to the IL1 receptor intracellular domain (TIR domain) (Chow et al. 1999).

The LPS-sensing machinery is constituted primarily by a LPS-binding protein (LBP), a glycosylphosphatidylinositol-anchored monocyte differentiation antigen (cluster of differentiation 14 (CD14)), an accessory protein (MD-2), and TLR4 (Bosshart \& Heinzelmann 2007). The primary role of LBP is the transportation of aggregates of circulating endotoxin, and the delivery of these molecules to CD14, resulting in cell activation, or to lipoproteins for hepatic clearance (Stoll et al. 2004). CD14 is a PRR with an important role in immunomodulation of proinflammatory signaling in response to LPS and other bacterial products (Kitchens \& Thompson 2005). It is also present in a soluble form (sCD14), which derives from the secretion of CD14 or the enzymatic cleavage of the membrane form (Turnbaugh et al. 2007). The accessory protein MD-2, which is associated with TLR4 on the cell surface, and appears to bind to TLR4 and endotoxin, is like CD14, also known to be a critical element in this receptor complex giving it responsiveness to LPS (Nagai et al. 2002). Due to lack of a transmembrane domain to CD14, TLRs are required for subsequent sinalization (Chow et al. 1999).

The pathway is primarily activated by lipid A, a LPS MAMP from the outer membrane of Gram-negative bacteria, which binds TLR4 and its co-receptors CD14 and MD-2. The TLR4 is thus activated, causing the recruitment of adaptor molecules through interactions

Published by Bioscientifica Ltd. 


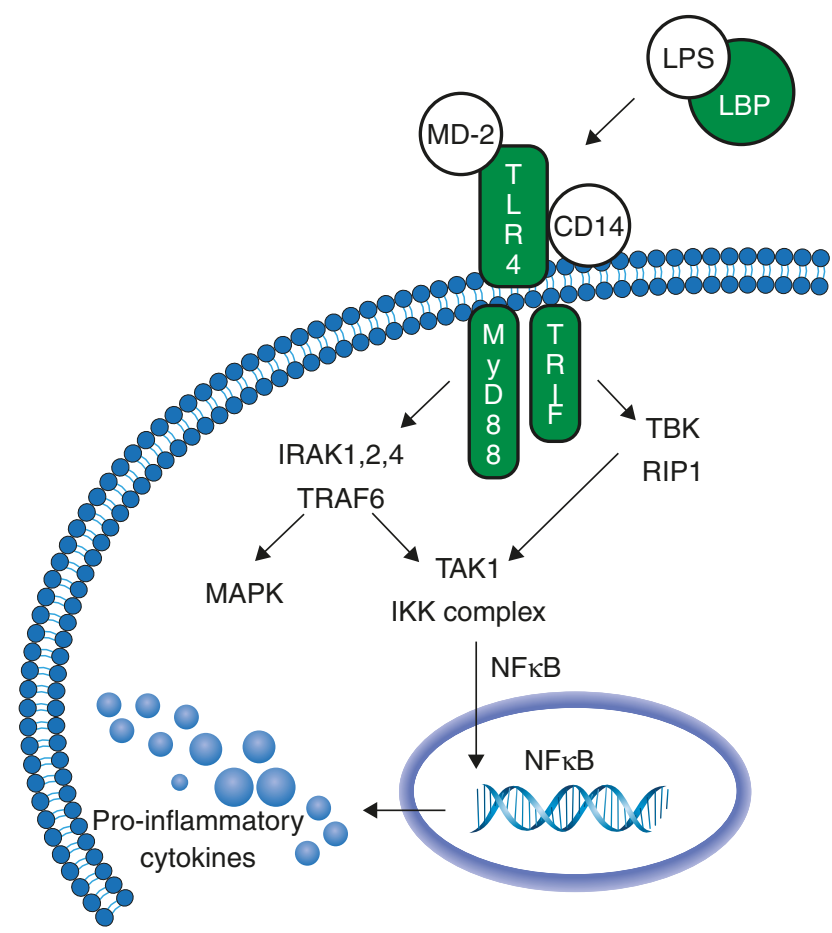

Figure 1

LPS-induced TLR4 activation induces the transcription of pro-inflammatory mediators, via the recruitment of adaptor molecules such as MyD88 and TRIF. LPS is mainly sensed through the activation of TLR4 by the LBP-LPS trigger complex. CD14 and MD-2 are critical elements in this receptor complex giving it responsiveness to LPS. TLR4 activation provokes the recruitment of four adaptor molecules, including MyD88 and TRIF. MyD88 activates the IKK complex via IRAK kinases/TRAF recruitment, lately leading to NFKB diffusion to the nucleus. TRAF6 activation also promotes MAPK activation and nuclear translocation, also inducing the transcription of pro-inflammatory cytokines. NFKB transcription also occurs in a MyD88-dependent pathway, via TRIF-mediated activation of the kinases TBK1 and RIP1. Full color version of this figure available via http://dx.doi.org/10.1530/JME-13-0079

with the TIR domain. There are four TLR4-TIR interacting adaptor molecules: MyD88; TIR domain-containing adaptor protein; TRIF-related adaptor molecule; and TRIF (TIR domain-containing adaptor inducing IFN- $\alpha$ ) (Medzhitov 2001; Fig. 1).

MyD88 recruits IRAK4, IRAK1, and IRAK2. IRAK kinases then phosphorylate and activate the protein TRAF6, which in turn polyubiquinates the protein TAK1 as well as itself in order to facilitate binding to IKK $\beta$. On binding, TAK1 phosphorylates IKK $\beta$, which then phosphorylates I $\mathrm{B}$ causing its degradation and allowing $\mathrm{NF} \kappa \mathrm{B}$ to diffuse into the cell nucleus and activate transcription (Lu et al. 2008; Fig. 1). TRAF6 activation also promotes MAPK-mediated AP-1 activation and nuclear translocation, inducing the transcription of proinflammatory cytokines. MyD88-independent intracellular pathways include TRIF-mediated activation of the kinases TBK1 and RIP1. The TRIF/TBK1 signaling complex phosphorylates IRF3 allowing its translocation into the nucleus and production of type I interferons. Moreover, RIP1 activation promotes TAK1 polyubiquination and activation and NFKB transcription in the same manner as the MyD88-dependent pathway (Werner \& Haller 2007). The major proinflammatory mediators produced by the TLR4 activation in response to endotoxin (LPS) are TNF $\alpha$, IL1 $\beta$ and IL6, which are also elevated in obese and insulinresistant patients (Parker et al. 2007).

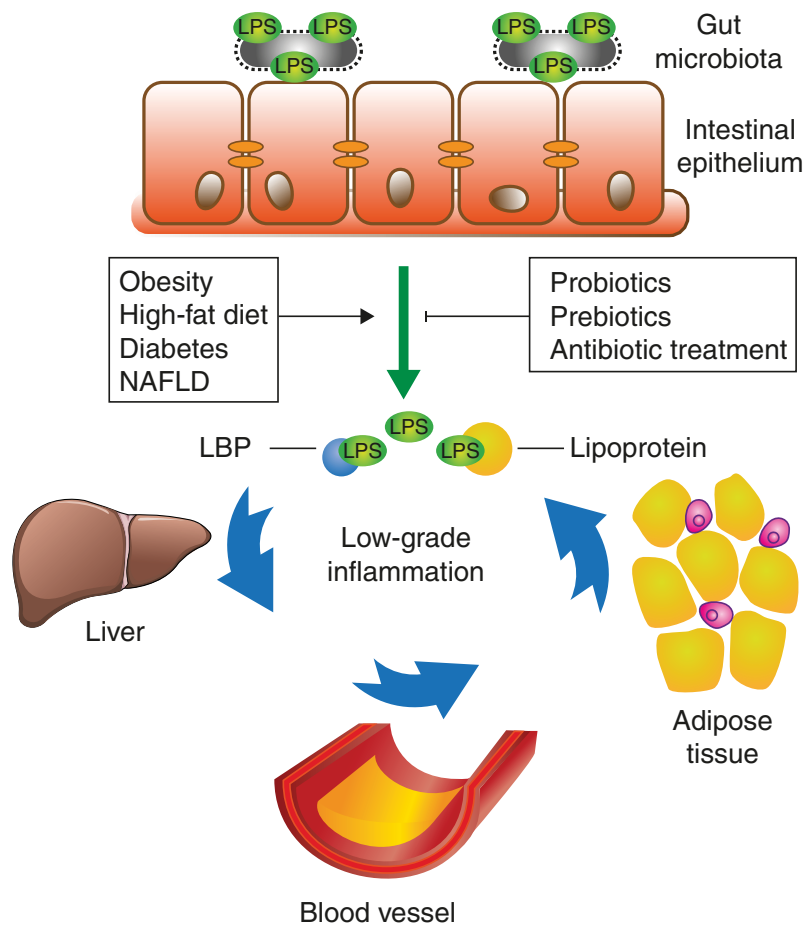

Figure 2

The gut epithelium is an efficient barrier that prevents absorption of LPS derived from Gram-negative gut microbiota. Obesity, high-fat diet, diabetes, and NAFLD are associated with higher gut permeability leading to metabolic endotoxemia. Probiotics, prebiotics, and antibiotic treatment can reduce LPS absorption and plasmatic levels. LPS in the bloodstream is transported by lipoproteins and LBP. In the liver, LPS is cleared by hepatocytes and excreted in the bile. LPS promotes hepatic insulin resistance, hypertriglyceridemia, hepatic triglyceride accumulation, and secretion of pro-inflammatory cytokines promoting the progression of fatty liver disease. In the endothelium, LPS induces the expression of pro-inflammatory, chemotactic, and adhesion molecules, which promotes atherosclerosis development and progression. In the adipose tissue, LPS induces adipogenesis, insulin resistance, macrophage infiltration, oxidative stress, and release of pro-inflammatory cytokines and chemokines. Full color version of this figure available via http://dx.doi.org/10.1530/ JME-13-0079

Published by Bioscientifica Ltd. 


\section{ME and CV risk}

Given the association between $\mathrm{ME}$ and proinflammatory activation, several potential mechanisms have been proposed to link the gut microbiome with $\mathrm{CV}$ risk (Cai et al. 2005, Cani et al. 2007a,b; Fig. 2; Table 1).

\section{ME and nutritional status}

The development of obesity is the result of complex interactions between genetic and environmental factors, which are only partially understood. In this context, the gut microbiota has been recently proposed to be an environmental factor involved in the control of body weight and energy homeostasis by modulating plasma LPS levels (Backhed et al. 2007, Cani et al. 2007a).

Experimental evidence showed that axenic mice (raised in the absence of microorganisms) had 40\% less total body fat than mice raised with normal gut microbiota (conventionalized), even if their caloric intake was higher than in conventionally raised animals (Backhed et al. 2004). Surprisingly, the conventionalization of axenic mice with microbiota previously harbored in nonaxenic mice was followed by a significant increase in fat mass (Backhed et al. 2004); moreover, mice conventionalized with microbiota from lean non-germ-free animals resulted in a fat mass gain of $40 \%$ (Backhed et al. 2004) and those conventionalized with the microbial community of genetically obese $(o b / o b)$ mice gained up to $60 \%$, although feed consumption was reduced in the latter (Turnbaugh et al. 2007). This difference in weight gain induced by conventionalization may be justified by different microbiomes and derived metabolites in lean and obese mice.

In order to understand how gut microbiota influences weight gain, germ-free and conventionalized mice were fed for 8 weeks with a high-fat, high-carbohydrate western diet. It was observed that germ-free mice gained significantly less weight and fat mass than conventionalized mice and were protected against western diet-induced insulin resistance (Backhed et al. 2007). This result suggests that dietary fats alone might not be sufficient to cause overweight and obesity, suggesting that a bacterially related factor might be responsible for high-fat diet-induced obesity.

Interestingly, Cani et al. demonstrated that after 4 weeks of high-fat feeding, mice exhibited a two- to threefold increase in circulating LPS levels, the so-called 'ME'. This was accompanied in high-fat-fed mice by a change in gut microbiota composition, with reduction in
Bifidobacterium and Eubacterium spp. (Cani et al. 2007a). In line with these observations, ME was shown to be present in genetically obese leptin-deficient mice (Brun et al. 2007). To further understand the effects of ME on weight gain, LPS was chronically infused in wild-type mice in order to achieve 'ME'. Interestingly, these animals showed increased body weight to the same extent as a 4-week high-fat diet regimen, with visceral and subcutaneous adipose depots increasing about 40 and 30\% respectively. This increase in body weight was not explained by excessive energy intake (Cani et al. 2007a).

In humans, it was also shown that meals with high-fat and high-carbohydrate content (fast-food style western diet) were able to decrease bifidobacteria levels and increase intestinal permeability and LPS concentrations (Ghanim et al. 2009, 2010, Fava et al. 2013). Moreover, it was demonstrated that, more than the fat amount, its composition was a critical modulator of ME (Laugerette et al. 2012). Very recently, Mani et al. (2013) demonstrated that LPS concentration was increased by a meal rich in saturated fatty acids (SFA), while decreased after a meal rich in n-3 polyunsaturated fatty acids (n-3 PUFA).

In fact, this effect seems to be due to the fact that some SFA (e.g., lauric and mystiric acids) are part of the lipid-A component of LPS and also to n-3 PUFA's role on reducing LPS potency when substituting SFA in lipid-A (Munford \& Hall 1986, Kitchens et al. 1992). To clarify the mechanisms of ME-induced innate immunity activation, mice lacking TLR4 co-receptor CD14 were studied. We have shown that CD14 KO mice when exposed to a high-fat highsimple carbohydrate diet show attenuation in CV and metabolic complications of obesity compared with wildtype mice (Roncon-Albuquerque et al. 2008). Moreover, when chronically injected with LPS, CD14 KO mice do not show body weight gain and increased visceral and subcutaneous adipose depots, as observed in wildtype animals (Cani et al. 2007a). Taken together, these experimental results suggest a pivotal role of CD14-mediated TLR4 activation in the development of LPS-mediated nutritional changes.

Studies have also been conducted where gut microbiota was manipulated by means of antibiotic treatment. This resulted in ME reduction and attenuation of obesity, fat mass development, mRNA concentration of adipose tissue inflammatory markers, and metabolic parameters of obesity in both high-fat-fed and $o b / o b$ mice (Cani et al. 2008, Membrez et al. 2008). Similar results were observed when an endotoxin inhibitor was administered for 4 weeks to $o b / o b$ mice (Cani et al. 2008).

Published by Bioscientifica Ltd. 

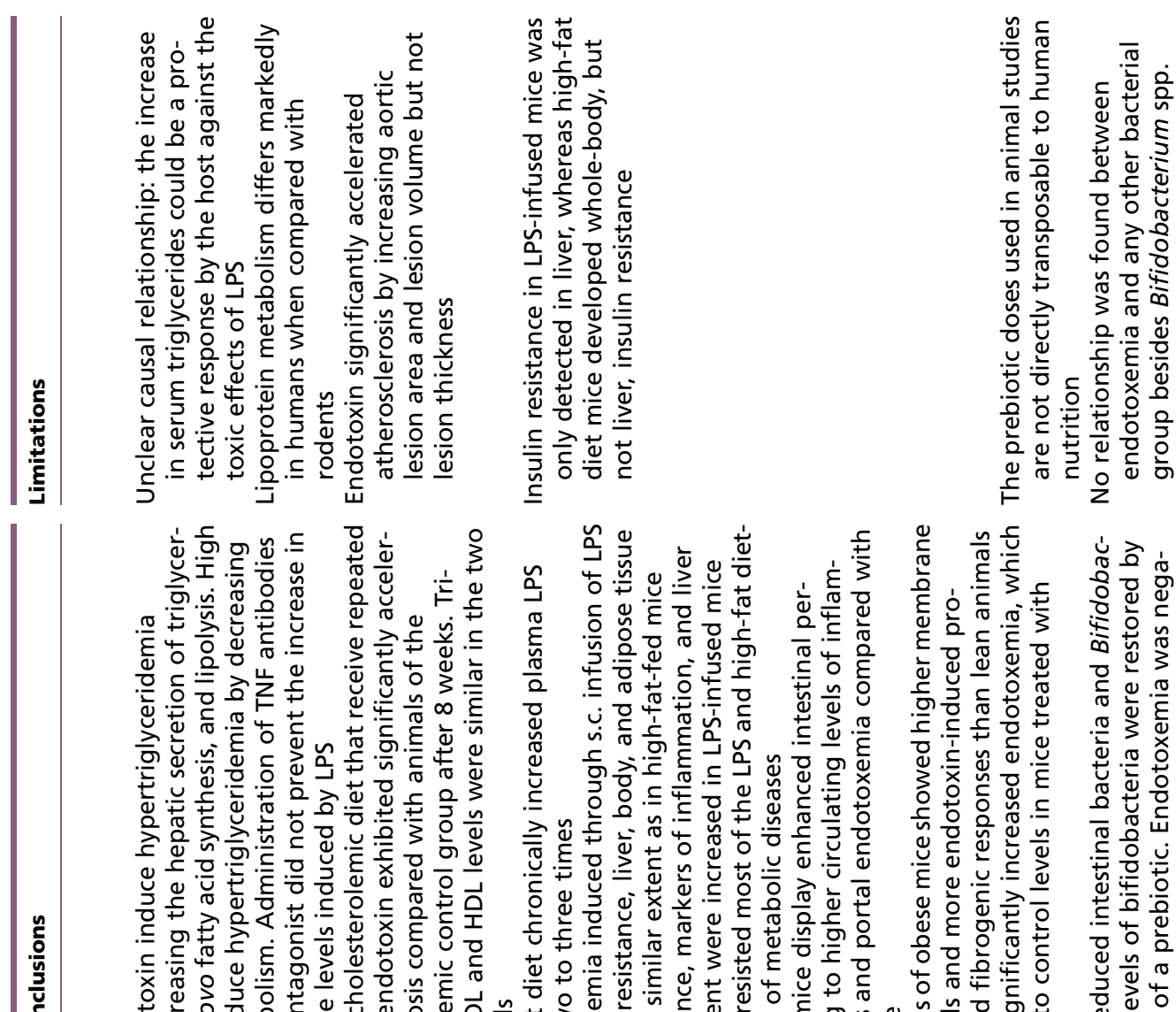

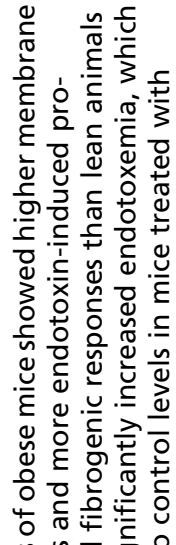

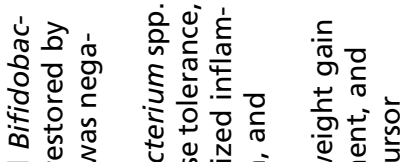

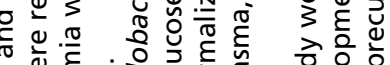

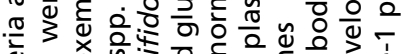

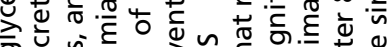

क⿹丁口

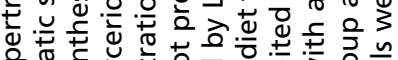

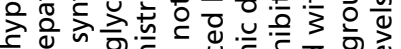

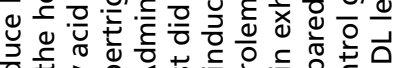

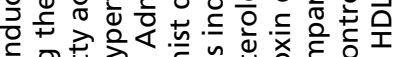

2

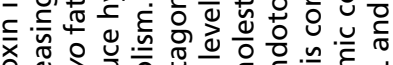

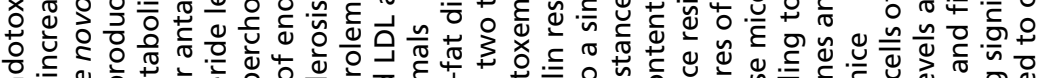

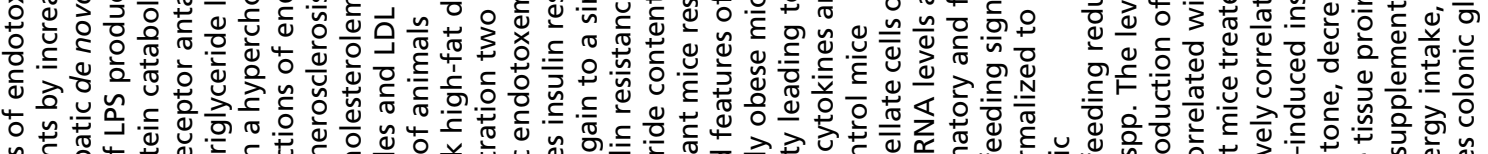

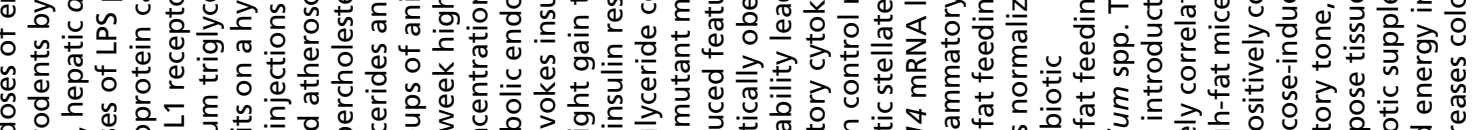

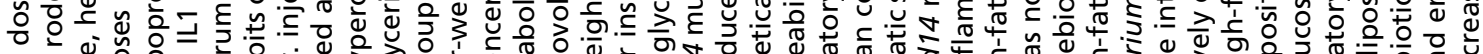

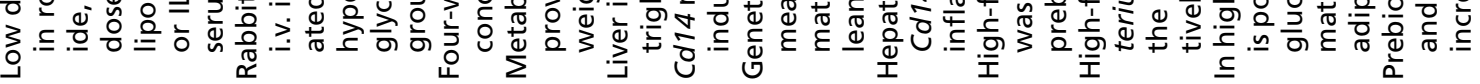$$
\text { 政 }
$$

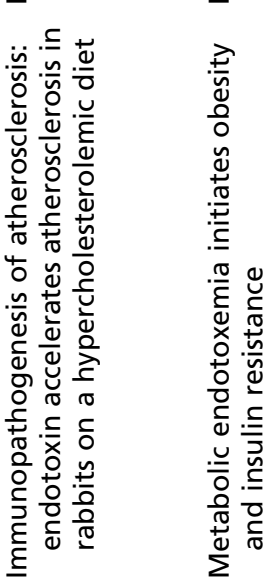
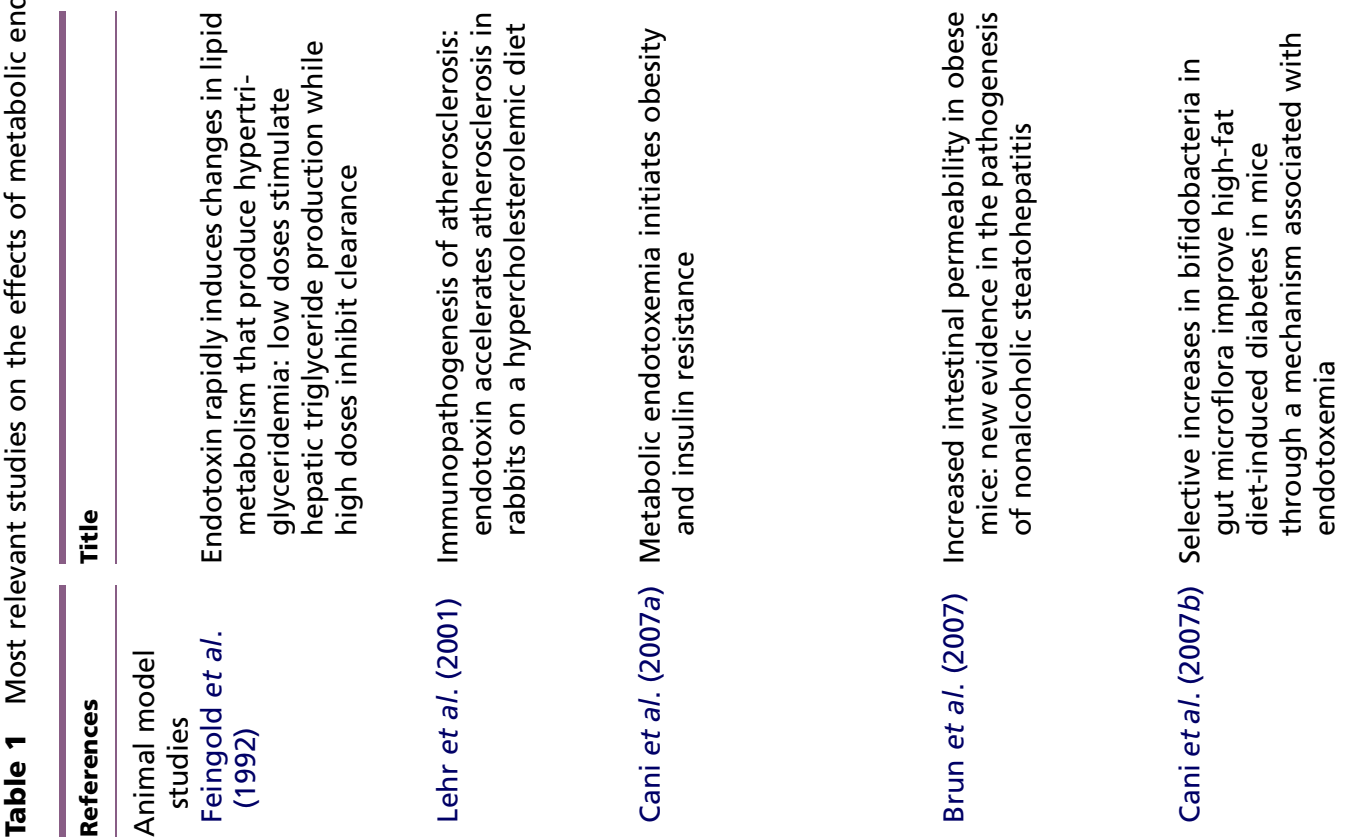


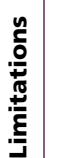
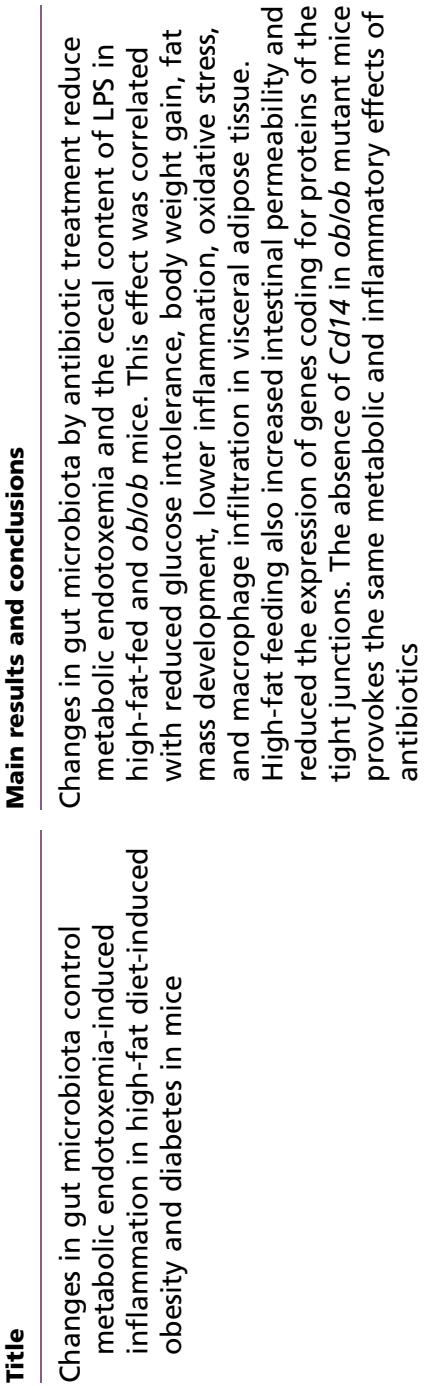
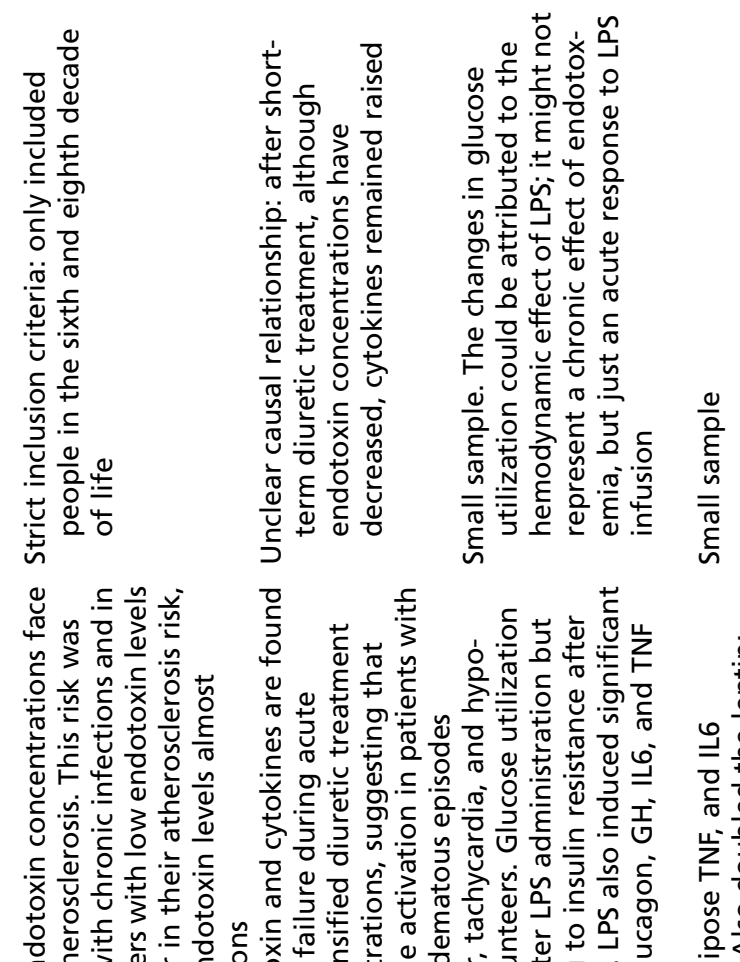

$\stackrel{\circ}{5}+\frac{5}{3}$

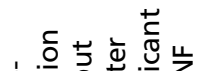
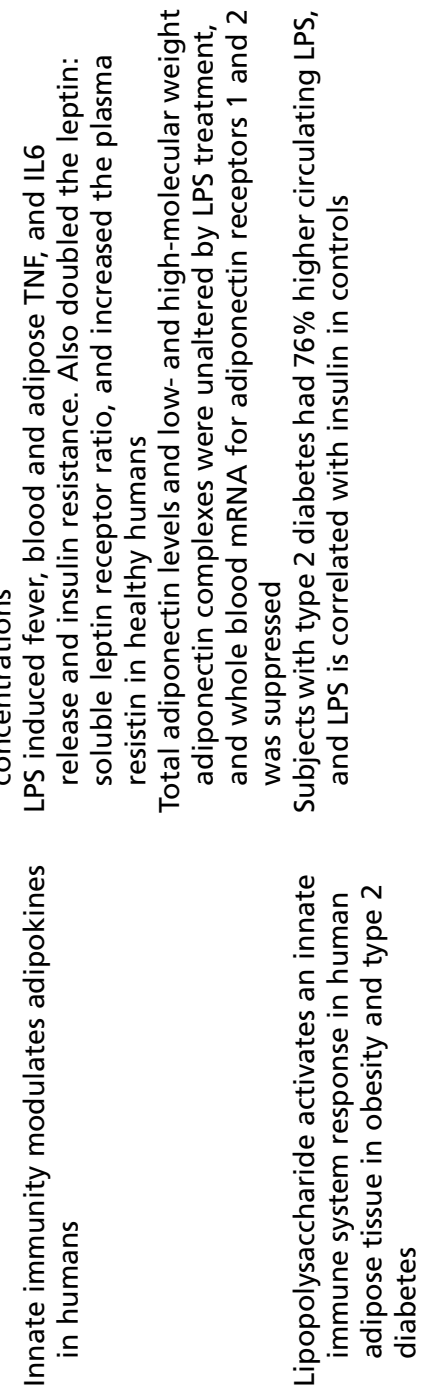
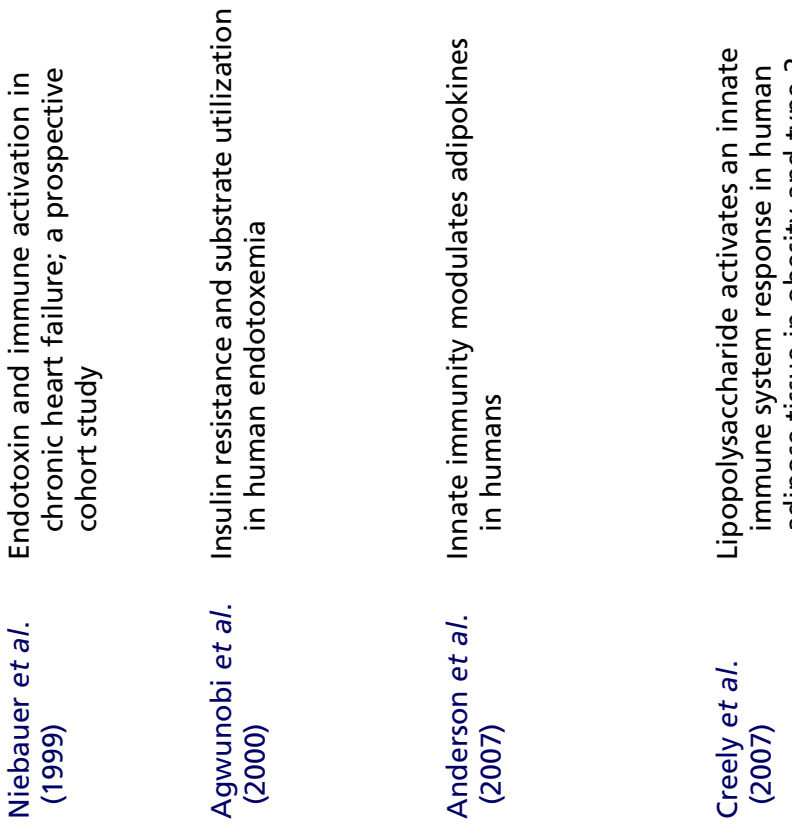


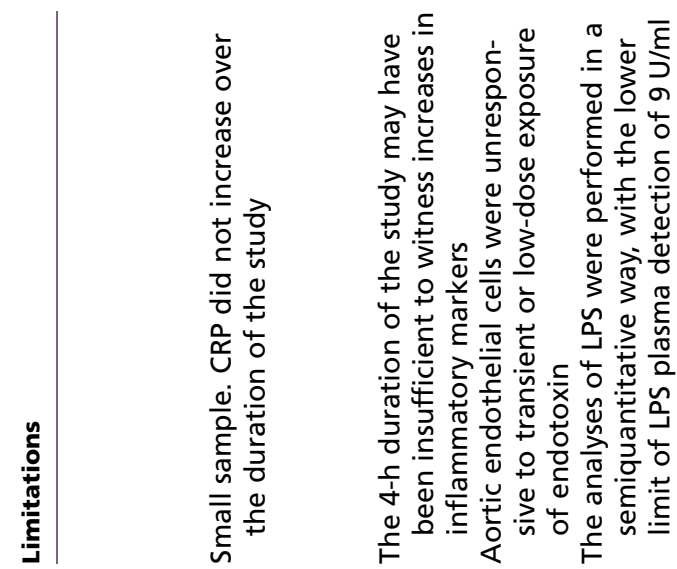
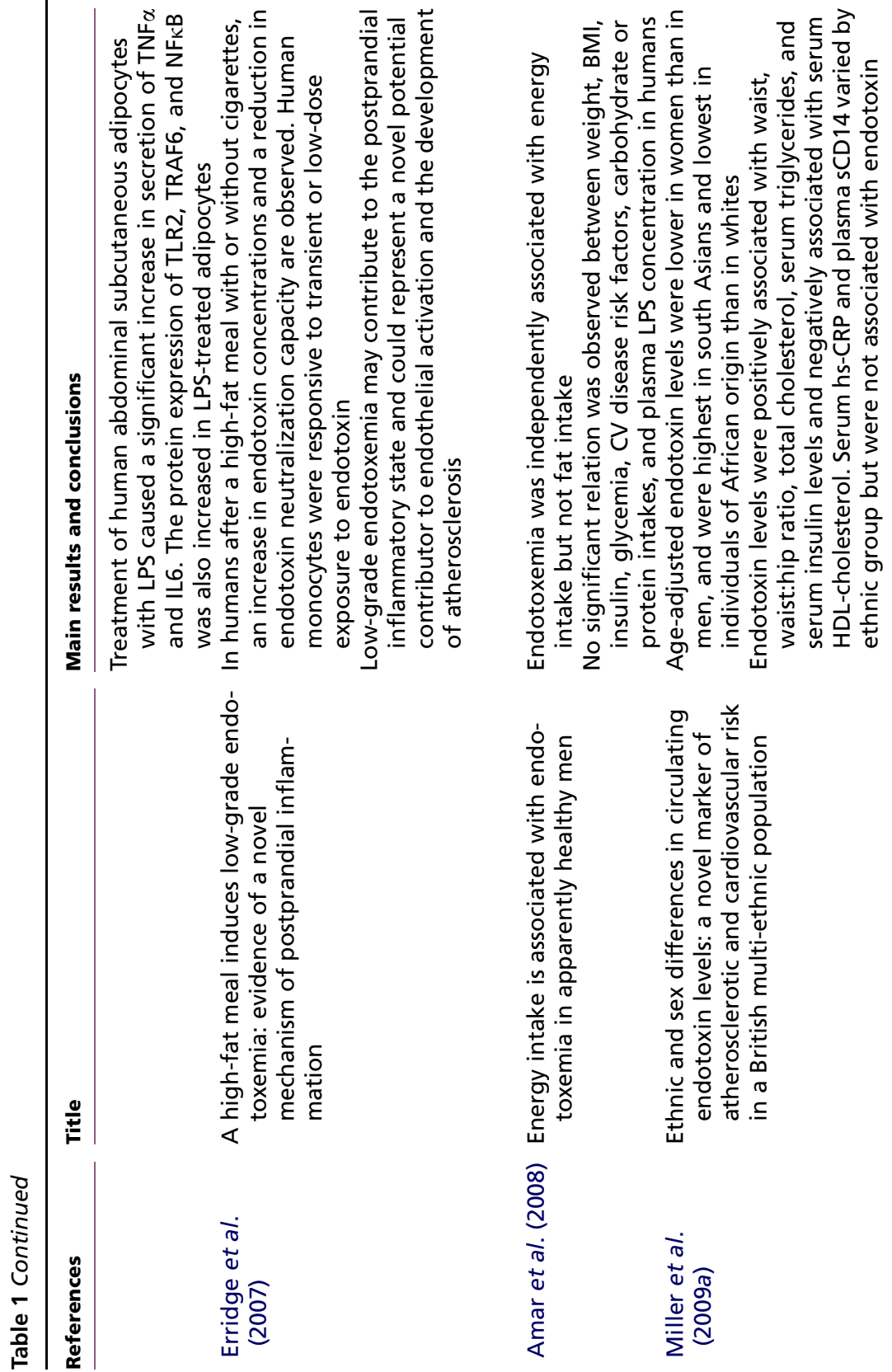
Other manipulations of gut microbiota include the use of pre- and probiotics. Prebiotics show efficacy in protecting against high-fat diet-induced $\mathrm{ME}$, also reducing body weight gain and fat mass (Cani et al. 2007b). This suggests a link between gut microbiota, western diet, and obesity and indicates that gut microbiota manipulation can beneficially affect the host's weight and adiposity. Although the data derived from animal models seem to support this link, the cause-effect relationships remain unclear and a limited number of in vivo trials have been performed so far. In one of the few cross-sectional studies performed in humans, endotoxemia was independently associated with energy intake but not fat intake in a multivariate analysis (Amar et al. 2008).

On the other hand, epidemiological studies strongly support that obesity and hypercholesterolemia paradoxically improve survival in cardiac cachexia, and thus, it would not be surprising that a hypercaloric and hyperproteic western diet could have some benefits in these cachectic patients (Song et al. 2006). This hypothesis has been tested in an animal model of monocrotaline-induced cardiac cachexia, being shown that in the group that consumed a western-type diet, the extent of myocardial remodeling and apoptosis were lower when compared with the group consuming a normal diet (Lourenco et al. 2011). The western-type diet group also had a more favorable inflammatory profile (lower myocardial NFאB transcription factor activity, endothelin-1 and cytokine overexpression and concentrations). Surprisingly, western-type diet attenuated cardiac cachexia and inflammation and improved survival, suggesting a relationship between the diet, inflammation, and CV risk in cachexia (Lourenco et al. 2011).

\section{ME and insulin resistance}

It has been proposed that ME and dietary fats might also impair carbohydrate metabolism up to insulin resistance and, lately, T2DM.

In vitro studies showed that preadipocytes mediate LPS-induced insulin resistance in primary cultures of newly differentiated human adipocytes. Chung et al. (2006) demonstrated in vitro that endotoxemia activates pro-inflammatory cytokine/chemokine production via $\mathrm{NF \kappa B}$ and MAPK signaling in preadipocytes and decreased peroxisome proliferator-activated receptor $\gamma$ activity and insulin responsiveness in adipocytes.

In order to study the relationship between $\mathrm{ME}$ and insulin resistance, LPS was continuously infused for 1 month in wild-type mice with a s.c. minipump to achieve 'ME'. These animals developed the same metabolic abnormalities as those usually induced by a high-fat diet, including hyperglycemia, hyperinsulinemia, and hepatic insulin resistance (Cani et al. 2007a). Moreover, CD14 KO mice were resistant to high-fat diet and chronic LPS infusion, showing hyperinsulinemia and insulin resistance significantly later when compared with wildtype animals. Of note, intrahepatic accumulation of triglycerides was totally blunted in CD14 KO mice. CD14 KO mice also showed hypersensitivity to insulin when fed a normal diet, suggesting a role for CD14 in the modulation of insulin sensitivity even in physiological conditions (Cani et al. 2007a).

Interventions manipulating the gut microbiome might also affect glycemic metabolism. Backhed et al. (2004) noticed that gut colonization of germ-free mice with cecum-derived microbes resulted in insulin resistance with no impact in chow consumption or energy expenditure.

A few studies in humans have also related ME to impaired glucidic metabolism. Creely et al. (2007) showed that T2DM patients have mean values of LPS that are 76\% higher than healthy controls. Plus, van der Crabben et al. showed that even low doses of LPS are able to induce changes in glucose uptake in lean humans, which presented enhanced insulin sensitivity in the first few hours after the injection, followed later by its significant reduction. Furthermore, circulating insulin and glucose levels were increased (Anderson et al. 2007, van der Crabben et al. 2009).

LPS exposure resulted in reduced hepatic glucose production and improved glucose clearance in healthy volunteers (van der Crabben et al. 2009, Raetzsch et al. 2009). This effect might be dependent on the LPS-induced release of glucagon, GH and cortisol, which inhibit glucose uptake, both peripheral and hepatic (Agwunobi et al. 2000).

Finally, LPSs also seem to induce ROS-mediated apoptosis in pancreatic cells. Du et al. showed that ROS-mediated LPS-induced apoptosis in insulin-secreting cells from a rat pancreatic cell line (ins-1) occurs in both dose- and time-dependent manners. This effect may lead to subsequent defective pancreatic cell function and decreased insulin secretion (Du et al. 2012).

\section{ME and dyslipidemia}

Recent evidence has been linking ME with dyslipidemia, increased intrahepatic triglycerides, development, and progression of alcoholic and nonalcoholic fatty liver disease (NAFLD; Manco et al. 2010).

Published by Bioscientifica Ltd. 
LPS is transported in the bloodstream by its specific transport protein (LBP) and by lipoproteins to hepatocytes (Netea et al. 2004). The hepatocytes, rather than hepatic macrophages, are the cells responsible for its clearance, being ultimately excreted in bile (Read et al. 1993). All the subclasses of plasma lipoproteins can bind and neutralize the toxic effects of LPS, both in vitro (Eichbaum et al. 1991) and in vivo (Harris et al. 1990), and this phenomenon seems to be dependent on the number of phospholipids in the lipoprotein surface (Levels et al. 2001). LDL seems to be involved in LPS clearance, but this antiatherogenic effect is outweighed by its proatherogenic features (Stoll et al. 2004).

LPS produces hypertriglyceridemia by several mechanisms, depending on LPS concentration. In animal models, low-dose LPS increases hepatic lipoprotein (such as VLDL) synthesis, whereas high-dose LPS decreases lipoprotein catabolism (Feingold et al. 1992, Sanz et al. 2008).

Some authors have pointed out that the high capacity of LPS binding to HDL suggests that HDL might provide additional protection against LPS-induced inflammation, like in sepsis or in the proatherogenic and diabetogenic effect observed in 'ME' (Barcia \& Harris 2005). Reinforcing this hypothesis, it was observed that an infusion of reconstituted HDL $3.5 \mathrm{~h}$ before a LPS challenge $(4 \mathrm{ng} / \mathrm{kg}$ ) markedly reduced LPS-induced release of TNF $\alpha$, IL6, and IL8 in humans (Pajkrt et al. 1996). Inversely, in a hypolipidemic rat model, LPS produced a three- to fivefold greater increase in TNF $\alpha$ levels when compared with controls (Feingold et al. 1995).

When a dose of LPS similar to that observed in ME was infused in humans, a 2.5-fold increase in endothelial lipase was observed, with consequent reduction in total and HDL. This mechanism may explain low HDL levels in 'ME' and other inflammatory conditions such as obesity and metabolic syndrome (Stoll et al. 2004).

It is known that the high-fat diet and the ' $\mathrm{ME}$ ' increase intrahepatic triglyceride accumulation, thus synergistically contributing to the development and progression of alcoholic and NAFLD, from the initial stages characterized by intrahepatic triglyceride accumulation up to chronic inflammation (nonalcoholic steatohepatitis), fibrosis, and cirrhosis (Manco et al. 2010). The increase in fatty acids in hepatocytes enhances the hepatic expression of TLR4 and TLR2, as well as its co-receptors CD14 and MD-2 (Maher et al. 2008). This favors activation by SFAs, LPSs, or both, enhancing the progression from fatty liver to steatohepatitis (Mencin et al. 2009). On the other hand, LPS activates Kupffer cells leading to an increased production of ROS and pro-inflammatory cytokines like TNF $\alpha$. This mechanism has been shown to promote the progression of fatty liver disease to steatohepatitis (Hritz et al. 2008).

Recently, it has been demonstrated that patients with NAFLD have a reduced expression of the tight junction protein zonula occludens 1, thus presenting increased intestinal permeability (Miele et al. 2009). It was also found that these patients' degree of intestinal permeability was proportional to their degree of steatosis. These changes in intestinal permeability have also been shown to promote ME (Miele et al. 2009).

The administration of prebiotics and probiotics in various models of liver disease, including NASH and LPS-induced liver failure resulted respectively in the inhibition of the inflammatory activity and improvement of NAFLD (Li et al. 2003) and in the prevention of hepatic damage (Ewaschuk et al. 2007).

\section{ME, low-grade inflammation, and oxidative stress}

Low-grade inflammation has been linked to CV risk, with several studies pointing out that increased levels of proinflammatory cytokines (C-reactive protein, soluble vascular cell adhesion molecule 1 , and intercellular adhesion molecule-1) are associated with higher CV mortality (Jager et al. 1999, Becker et al. 2002, Danesh et al. 2004).

ME seems to participate in this molecular pathway, acting as a trigger to the low-grade inflammatory response. In a previously described animal model, Cani et al. changed gut microbiota by means of antibiotic treatment to demonstrate that changes in gut microbiota could be responsible for the control of ME and low-grade inflammation. The authors first showed that high-fat diet mice presented with ME, which positively and significantly correlated with plasminogen activator inhibitor (PAI-1), IL1, TNF $\alpha$, STAMP2, NADPHox, MCP-1, and F4/80 (a specific marker of mature macrophages) mRNAs (Cani et al. 2008). Subsequently, in a different interventional study, it was also shown that prebiotic administration reduces intestinal permeability to LPS in obese mice and is associated with decreased systemic inflammation when compared with controls. Changing the gut microbiota through an intervention was associated with significantly reduced Pai-1, Cd68, Nadph oxidase (NadpHox), and inducible nitric oxide synthase mRNA concentrations and tended to decrease Tlr4 and Tnf $\alpha$ mRNA concentrations (Cani et al. 2008).

LPS also seems to affect oxidative stress, which has also been implied in CV morbidity and mortality. We have shown that allelic variants of $(\mathrm{Cu}-\mathrm{Zn}) \mathrm{SOD}$, an enzyme

Published by Bioscientifica Ltd. 
belonging to the superoxide dismutase family and that play a major role in detoxification of ROS and protection against oxidative stress, are associated with increased risk of death from CV causes (sudden death, fatal myocardial infarction, or stroke) (Neves et al. 2012). Gibbs et al. (1992) demonstrated that lung endothelial MnSOD (both mRNA and protein) was increased by LPS treatment in LPS-sensitive mice, but not in LPS-resistant mice. Conversely, TNF $\alpha$ increased MnSOD mRNA levels in both models, LPS-sensitive and resistant. On the other hand, LPS exposure did not affect either macrophage or endothelial cell Cu/ZnSOD mRNA/protein levels (Gibbs et al. 1992). These findings suggest that the mutation that shapes LPS susceptibility probably exerts its effect in a cell-specific way (Gibbs et al. 1992). Tsan et al. (2001) additionally demonstrated that induction of MnSOD by LPS is mediated by MCD14 and TLR4 in murine macrophages.

Cani $e t$ al. also found that high-fat diet mice presented with not only ME but also higher levels of inflammatory markers, oxidative stress, and macrophage infiltration markers. Plus, positive and significant correlations were found among these variables. This suggests that important links between gut microbiota, ME, inflammation, and oxidative stress are implicated in a high-fat diet situation (Cani et al. 2008). Plus, the authors showed that the antibiotic treatment completely abolished these effects, normalizing not only the increase in inflammatory markers but also normalizing lipid peroxidation in the visceral depots and the oxidative stress markers STAMP2 and NADPHox on visceral and subcutaneous adipose depots. The mRNA concentrations of chemokines MCP-1 and F4/80 were increased in high-fat mice and totally normalized by the antibiotic treatment.

These results are also supported by previous studies that have described that high-fat feeding is associated with adipose tissue macrophage infiltration (F4/80-positive cells) and increased levels of chemokine MCP-1, suggesting a strong link between $\mathrm{ME}$, proinflammatory status, oxidative stress, and, lately, increased CV risk (Weisberg et al. 2003, Kanda et al. 2006).

\section{ME and CV disease}

As described above, ME relates to several known CV risk factors and lately promotes low-grade chronic inflammation and oxidative stress, two recognized factors of $\mathrm{CV}$ disease. Thus, it is not surprising that ME is also associated with real target-organ CV disease. Discussed as follows, LPS has been shown to promote atherosclerosis, a hallmark of CV disease.
The effect of LPS on the CV system was demonstrated in patients with chronic kidney disease (CKD), in which ME correlated with the CV disease burden (systemic inflammation and cardiac injury) and with a higher risk of mortality. The authors suggest that CKD patients, namely those undergoing hemodialysis, experience systemic circulatory stress and recurrent regional ischemia that contributes to increased LPS translocation through the intestinal barrier (McIntyre et al. 2011).

In order to specifically demonstrate the effect of LPS on the development of atherosclerosis, Lehr et al. showed that LPS-treated animals exhibited significantly accelerated atherosclerosis compared with control animals, using an animal model of hypercholesterolemic rabbits, which received either repeated i.v. injections of endotoxin or a self-limiting cutaneous Staphylococcus aureus infection. Endotoxin-treated animals exhibited significantly accelerated atherosclerosis compared with control animals (Lehr et al. 2001).

In humans, the Bruneck study was the first specifically assessing the impact of subclinical endotoxemia on the development of carotid atherosclerosis. The authors showed that markers of systemic inflammation such as circulating bacterial endotoxin were elevated in patients with chronic infections and were strong predictors of increased atherosclerotic risk (Kiechl et al. 2001).

Several molecular mechanisms explain the role of LPS in atherosclerotic plaque formation and progression. As previously described, under endotoxemic conditions, endothelial cells release proinflammatory, chemotactic, and adhesion molecules, drawing $\mathrm{T}$ lymphocytes to form the fibrous cap of atherosclerotic lesions (Larsen et al. 1989) and inducing monocyte transmigration, adhesion on the endothelial monolayer, differentiation into macrophages, and plaque formation (Gerszten et al. 1999). Endotoxin can also induce activation and up-regulation of other molecules involved in cell-cell and cell-matrix interaction and communication, such as $\beta 2$-integrins, selectins, platelet/endothelial cell adhesion molecule-1, and platelet-activating factor (Shen et al. 1998).

Plus, Wiesner et al. (2010) suggested that cooperative engagement of $\mathrm{NF} \kappa \mathrm{B}$ transcription factors by $\mathrm{mmLDL}$ and LPS results in additive/synergistic upregulation of proinflammatory genes in macrophages, thus constituting a mechanism of increased transcription of inflammatory cytokines within atherosclerotic lesions.

As a TLR4 ligand, LPS has been suggested to induce atherosclerosis development and progression, via a TLR4-mediated inflammatory state. Michelsen et al. (2004) showed that mice lacking TLR4 presented with

Published by Bioscientifica Ltd. 
reduced aortic atherosclerosis, lower levels of circulatory proinflammatory cytokines, and decreased lipid content in the plaques. On the other hand, Miller et al. (2009b) used a zebrafish model of early stages of atherosclerosis, which demonstrated that lack of TLR resulted in a significant decrease in the in vivo rate of lipidic accumulation on macrophages present on vascular lesions.

In humans, TLR4 mutations have been shown to be associated with a decreased response to inhaled LPS (Arbour et al. 2000). Plus, a reduced risk of carotid artery atherosclerosis development (Kiechl et al. 2002) and the appearance of acute coronary events have been observed in association with its Asp299Gly polymorphism (Ameziane et al. 2003, Boekholdt et al. 2003).

\section{Conclusion}

The intestinal microbiome gained growing interest as a modulator of inflammation and oxidative stress, factors increasingly implicated in the pathophysiology of $\mathrm{CV}$ disease. According to the actual evidence, some authors have suggested that it might have itself a role as a CV risk marker. Nevertheless, several questions remain to be answered (Box 1).

First, the factors influencing LPS translocation are not completely understood and might be addressed in future studies. As discussed before, high-fat and high-carbohydrate content (fast-food style western diet) increase intestinal permeability and LPS concentrations. Thus, it would not be surprising that other characteristics of dietary components might also play a role in LPS translocation $(\mathrm{pH}$, salt or sucrose content, other dietary nutrients). Very recently, it has been found that high levels of trimethylamine N-oxide, a product of phosphatidylcholine digestion by intestinal bacteria, are associated with increased risk of incident major CV events (Tang et al. 2013). The study and modulation of other dietary component effects might lead to novel additional research lines on this field.

Box 1 Future research lines

1) Other factors influencing LPS absorption/translocation a. Environmental factors

i. Other dietary characteristics and components (e.g., pH, salt content, sucrose content, other dietary nutrients); therapeutic options modulating these components

b. Genetic factors

2) Identification of other LPS-mediated pathways leading to $\mathrm{CV}$ disease

3) Epidemiological studies

http://jme.endocrinology-journals.org DOI: 10.1530/JME-13-0079

C) 2013 Society for Endocrinology Printed in Great Britain
Plus, genetic determinants may also play a role in LPS translocation; in intestinal bowel disease, some genetic factors (such as mutation of CARD15) are involved in the impairment of intestinal barrier function and high mucosal permeability (Schreiber 2006). In CV disease, mutations leading to increased gut permeability can also lead to a higher probability of developing ME in response to the environmental factors such as nutrition. This could explain why CV disease develops differently in patients exposed to the same environmental conditions, thus integrating the genetic environmental concepts.

Finally, the relationship between ME and CV disease shall be further clarified by epidemiologically robust evidence. The Bruneck study was the first to evoke a clinical association between LPS levels and CV risk (Wiedermann et al. 1999). More recently, the Wandsworth Heart and Stroke Study showed an ethnic influence on LPS levels, which increased from black Africans to caucasians and to south Asians (Miller et al. 2009a). The authors pointed out that this increase was compatible with ethnic differences in CV risk, as an increase in the number of components of the metabolic syndrome and in 10-year $\mathrm{CV}$ risk (Framingham score) was also observed. Although compelling evidence suggests a molecular link between $\mathrm{ME}$ and $\mathrm{CV}$ risk, more powerful epidemiological studies are needed to clarify the strength of this association.

Finally, research lines addressing the understanding of LPS-mediated pathways leading to CV disease may also lead to the identification of other molecules that also contribute to this disease. A better understanding of these molecular mechanisms may unravel novel and innovative therapeutic approaches to reduce CV risk.

\section{Declaration of interest}

The authors declare that there is no conflict of interest that could be perceived as prejudicing the impartiality of the review.

\section{Funding}

This work was supported by Portuguese Foundation for Science and Technology Grants PEst-C/SAU/UI0051/2011 and PTDC/SAU-MET/116119/09 through the Cardiovascular R\&D Unit and SFRH/BD/52036/2012.

\section{References}

Agwunobi AO, Reid C, Maycock P, Little RA \& Carlson GL 2000 Insulin resistance and substrate utilization in human endotoxemia. Journal of Clinical Endocrinology and Metabolism 85 3770-3778. (doi:10.1210/ jc.85.10.3770)

Amar J, Burcelin R, Ruidavets JB, Cani PD, Fauvel J, Alessi MC, Chamontin B \& Ferrieres J 2008 Energy intake is associated with endotoxemia in apparently healthy men. American Journal of Clinical Nutrition 87 1219-1223.

Published by Bioscientifica Ltd. 
Ameziane N, Beillat T, Verpillat P, Chollet-Martin S, Aumont MC, Seknadji P, Lamotte M, Lebret D, Ollivier V \& de Prost D 2003 Association of the Toll-like receptor 4 gene Asp299Gly polymorphism with acute coronary events. Arteriosclerosis, Thrombosis, and Vascular Biology 23 e61-e64. (doi:10.1161/01.ATV.0000101191.92392.1D)

Anderson PD, Mehta NN, Wolfe ML, Hinkle CC, Pruscino L, Comiskey LL, Tabita-Martinez J, Sellers KF, Rickels MR, Ahima RS et al. 2007 Innate immunity modulates adipokines in humans. Journal of Clinical Endocrinology and Metabolism 92 2272-2279. (doi:10.1210/jc.2006-2545)

Arbour NC, Lorenz E, Schutte BC, Zabner J, Kline JN, Jones M, Frees K, Watt JL \& Schwartz DA 2000 TLR4 mutations are associated with endotoxin hyporesponsiveness in humans. Nature Genetics 25 187-191. (doi:10.1038/76048)

Backhed F, Ding H, Wang T, Hooper LV, Koh GY, Nagy A, Semenkovich CF \& Gordon JI 2004 The gut microbiota as an environmental factor that regulates fat storage. PNAS 101 15718-15723. (doi:10.1073/pnas. 0407076101)

Backhed F, Manchester JK, Semenkovich CF \& Gordon JI 2007 Mechanisms underlying the resistance to diet-induced obesity in germ-free mice. PNAS 104 979-984. (doi:10.1073/pnas.0605374104)

Barcia AM \& Harris HW 2005 Triglyceride-rich lipoproteins as agents of innate immunity. Clinical Infectious Diseases 41 (Suppl 7) S498-S503. (doi:10.1086/432005)

Becker A, van Hinsbergh VW, Jager A, Kostense PJ, Dekker JM, Nijpels G, Heine RJ, Bouter LM \& Stehouwer CD 2002 Why is soluble intercellular adhesion molecule-1 related to cardiovascular mortality? European Journal of Clinical Investigation 32 1-8. (doi:10.1046/j.1365-2362.2002. 00919.x)

Boekholdt SM, Agema WR, Peters RJ, Zwinderman AH, van der Wall EE, Reitsma PH, Kastelein JJ, Jukema JW \& Group REGESS 2003 Variants of toll-like receptor 4 modify the efficacy of statin therapy and the risk of cardiovascular events. Circulation 107 2416-2421. (doi:10.1161/01. CIR.0000068311.40161.28)

Bosshart H \& Heinzelmann M 2007 Targeting bacterial endotoxin: two sides of a coin. Annals of the New York Academy of Sciences 1096 1-17. (doi:10.1196/annals.1397.064)

Brun P, Castagliuolo I, Di Leo V, Buda A, Pinzani M, Palu G \& Martines D 2007 Increased intestinal permeability in obese mice: new evidence in the pathogenesis of nonalcoholic steatohepatitis. American Journal of Physiology. Gastrointestinal and Liver Physiology 292 G518-G525. (doi:10.1152/ajpgi.00024.2006)

Cai D, Yuan M, Frantz DF, Melendez PA, Hansen L, Lee J \& Shoelson SE 2005 Local and systemic insulin resistance resulting from hepatic activation of IKK- $\beta$ and NF- $\mathrm{B}$. Nature Medicine 11 183-190. (doi:10.1038/nm1166)

Cani PD, Amar J, Iglesias MA, Poggi M, Knauf C, Bastelica D, Neyrinck AM, Fava F, Tuohy KM, Chabo C et al. 2007a Metabolic endotoxemia initiates obesity and insulin resistance. Diabetes 56 1761-1772. (doi:10.2337/db06-1491)

Cani PD, Neyrinck AM, Fava F, Knauf C, Burcelin RG, Tuohy KM, Gibson GR \& Delzenne NM 2007b Selective increases of bifidobacteria in gut microflora improve high-fat-diet-induced diabetes in mice through a mechanism associated with endotoxaemia. Diabetologia 50 2374-2383. (doi:10.1007/s00125-007-0791-0)

Cani PD, Bibiloni R, Knauf C, Waget A, Neyrinck AM, Delzenne NM \& Burcelin R 2008 Changes in gut microbiota control metabolic endotoxemia-induced inflammation in high-fat diet-induced obesity and diabetes in mice. Diabetes 57 1470-1481. (doi:10.2337/db07-1403)

Chow JC, Young DW, Golenbock DT, Christ WJ \& Gusovsky F 1999 Toll-like receptor-4 mediates lipopolysaccharide-induced signal transduction. Journal of Biological Chemistry 274 10689-10692. (doi:10.1074/jbc.274.16.10689)

Chung S, Lapoint K, Martinez K, Kennedy A, Boysen Sandberg M \& McIntosh MK 2006 Preadipocytes mediate lipopolysaccharide-induced inflammation and insulin resistance in primary cultures of newly differentiated human adipocytes. Endocrinology 147 5340-5351. (doi:10.1210/en.2006-0536)

van der Crabben SN, Blumer RM, Stegenga ME, Ackermans MT, Endert E, Tanck MW, Serlie MJ, van der Poll T \& Sauerwein HP 2009 Early endotoxemia increases peripheral and hepatic insulin sensitivity in healthy humans. Journal of Clinical Endocrinology and Metabolism 94 463-468. (doi:10.1210/jc.2008-0761)

Creely SJ, McTernan PG, Kusminski CM, Fisher FM, Da Silva NF, Khanolkar M, Evans M, Harte AL \& Kumar S 2007 Lipopolysaccharide activates an innate immune system response in human adipose tissue in obesity and type 2 diabetes. American Journal of Physiology. Endocrinology and Metabolism 292 E740-E747. (doi:10.1152/ajpendo.00302.2006)

Danesh J, Wheeler JG, Hirschfield GM, Eda S, Eiriksdottir G, Rumley A, Lowe GD, Pepys MB \& Gudnason V 2004 C-reactive protein and other circulating markers of inflammation in the prediction of coronary heart disease. New England Journal of Medicine 350 1387-1397. (doi:10.1056/ NEJMoa032804)

Du SC, Ge QM, Lin N, Dong Y \& Su Q 2012 ROS-mediated lipopolysaccharide-induced apoptosis in INS-1 cells by modulation of Bcl-2 and Bax. Cellular and Molecular Biology 58 (Suppl) OL1654-OL1659.

Eichbaum EB, Harris HW, Kane JP \& Rapp JH 1991 Chylomicrons can inhibit endotoxin activity in vitro. Journal of Surgical Research $\mathbf{5 1}$ 413-416. (doi:10.1016/0022-4804(91)90143-A)

Erridge C, Attina T, Spickett CM \& Webb DJ 2007 A high-fat meal induces low-grade endotoxemia: evidence of a novel mechanism of postprandial inflammation. American Journal of Clinical Nutrition 86 1286-1292.

Ewaschuk J, Endersby R, Thiel D, Diaz H, Backer J, Ma M, Churchill T \& Madsen K 2007 Probiotic bacteria prevent hepatic damage and maintain colonic barrier function in a mouse model of sepsis. Hepatology 46 841-850. (doi:10.1002/hep.21750)

Fava F, Gitau R, Griffin BA, Gibson GR, Tuohy KM \& Lovegrove JA 2013 The type and quantity of dietary fat and carbohydrate alter faecal microbiome and short-chain fatty acid excretion in a metabolic syndrome 'at-risk' population. International Journal of Obesity 37 216-223. (doi:10.1038/ijo.2012.33)

Feingold KR, Staprans I, Memon RA, Moser AH, Shigenaga JK, Doerrler W, Dinarello CA \& Grunfeld C 1992 Endotoxin rapidly induces changes in lipid metabolism that produce hypertriglyceridemia: low doses stimulate hepatic triglyceride production while high doses inhibit clearance. Journal of Lipid Research 33 1765-1776.

Feingold KR, Funk JL, Moser AH, Shigenaga JK, Rapp JH \& Grunfeld C 1995 Role for circulating lipoproteins in protection from endotoxin toxicity. Infection and Immunity 63 2041-2046.

Gerszten RE, Garcia-Zepeda EA, Lim YC, Yoshida M, Ding HA, Gimbrone MAJr, Luster AD, Luscinskas FW \& Rosenzweig A 1999 MCP-1 and IL-8 trigger firm adhesion of monocytes to vascular endothelium under flow conditions. Nature 398 718-723. (doi:10.1038/19546)

Ghanim H, Abuaysheh S, Sia CL, Korzeniewski K, Chaudhuri A, Fernandez-Real JM \& Dandona P 2009 Increase in plasma endotoxin concentrations and the expression of Toll-like receptors and suppressor of cytokine signaling-3 in mononuclear cells after a high-fat, high-carbohydrate meal: implications for insulin resistance. Diabetes Care 32 2281-2287. (doi:10.2337/dc09-0979)

Ghanim H, Sia CL, Upadhyay M, Korzeniewski K, Viswanathan P, Abuaysheh S, Mohanty P \& Dandona P 2010 Orange juice neutralizes the proinflammatory effect of a high-fat, high-carbohydrate meal and prevents endotoxin increase and Toll-like receptor expression. American Journal of Clinical Nutrition 91 940-949. (doi:10.3945/ajcn. 2009.28584)

Ghoshal S, Witta J, Zhong J, de Villiers W \& Eckhardt E 2009 Chylomicrons promote intestinal absorption of lipopolysaccharides. Journal of Lipid Research 50 90-97. (doi:10.1194/jlr.M800156-JLR200)

Gibbs LS, Del Vecchio PJ \& Shaffer JB $1992 \mathrm{Mn}$ and Cu/Zn SOD expression in cells from LPS-sensitive and LPS-resistant mice. Free Radical Biology \& Medicine 12 107-111. (doi:10.1016/0891-5849(92)90003-Y) http://jme.endocrinology-journals.org DOI: 10.1530/JME-13-0079
() 2013 Society for Endocrinology Printed in Great Britain 
Harris HW, Grunfeld C, Feingold KR \& Rapp JH 1990 Human very low density lipoproteins and chylomicrons can protect against endotoxininduced death in mice. Journal of Clinical Investigation 86 696-702. (doi:10.1172/JCI114765)

Hathaway LJ \& Kraehenbuhl JP 2000 The role of M cells in mucosal immunity. Cellular and Molecular Life Sciences 57 323-332. (doi:10.1007/PL00000693)

Hooper LV \& Gordon JI 2001 Commensal host-bacterial relationships in the gut. Science 292 1115-1118. (doi:10.1126/science.1058709)

Hornef MW, Normark BH, Vandewalle A \& Normark S 2003 Intracellular recognition of lipopolysaccharide by toll-like receptor 4 in intestinal epithelial cells. Journal of Experimental Medicine 198 1225-1235. (doi:10.1084/jem.20022194)

Hritz I, Mandrekar P, Velayudham A, Catalano D, Dolganiuc A, Kodys K, Kurt-Jones E \& Szabo G 2008 The critical role of toll-like receptor (TLR) 4 in alcoholic liver disease is independent of the common TLR adapter MyD88. Hepatology 48 1224-1231. (doi:10.1002/hep.22470)

Jager A, van Hinsbergh VW, Kostense PJ, Emeis JJ, Yudkin JS, Nijpels G, Dekker JM, Heine RJ, Bouter LM \& Stehouwer CD 1999 von Willebrand factor, C-reactive protein, and 5-year mortality in diabetic and nondiabetic subjects: the Hoorn Study. Arteriosclerosis, Thrombosis, and Vascular Biology 19 3071-3078. (doi:10.1161/01.ATV.19.12.3071)

Kanda H, Tateya S, Tamori Y, Kotani K, Hiasa K, Kitazawa R, Kitazawa S, Miyachi H, Maeda S, Egashira K et al. 2006 MCP-1 contributes to macrophage infiltration into adipose tissue, insulin resistance, and hepatic steatosis in obesity. Journal of Clinical Investigation 116 1494-1505. (doi:10.1172/JCI26498)

Kelly D \& Conway S 2005 Bacterial modulation of mucosal innate immunity. Molecular Immunology 42 895-901. (doi:10.1016/j.molimm. 2004.12.003)

Kiechl S, Egger G, Mayr M, Wiedermann CJ, Bonora E, Oberhollenzer F, Muggeo M, Xu Q, Wick G, Poewe W et al. 2001 Chronic infections and the risk of carotid atherosclerosis: prospective results from a large population study. Circulation 103 1064-1070. (doi:10.1161/01.CIR. 103.8.1064)

Kiechl S, Lorenz E, Reindl M, Wiedermann CJ, Oberhollenzer F, Bonora E, Willeit J \& Schwartz DA 2002 Toll-like receptor 4 polymorphisms and atherogenesis. New England Journal of Medicine 347 185-192. (doi:10.1056/NEJMoa012673)

Kitchens RL \& Thompson PA 2005 Modulatory effects of sCD14 and LBP on LPS-host cell interactions. Journal of Endotoxin Research 11 225-229.

Kitchens RL, Ulevitch RJ \& Munford RS 1992 Lipopolysaccharide (LPS) partial structures inhibit responses to LPS in a human macrophage cell line without inhibiting LPS uptake by a CD14-mediated pathway. Journal of Experimental Medicine 176 485-494. (doi:10.1084/jem.176.2.485)

Larsen CG, Anderson AO, Appella E, Oppenheim JJ \& Matsushima K 1989 The neutrophil-activating protein (NAP-1) is also chemotactic for T lymphocytes. Science 243 1464-1466. (doi:10.1126/science.2648569)

Laugerette F, Furet JP, Debard C, Daira P, Loizon E, Geloen A, Soulage CO, Simonet C, Lefils-Lacourtablaise J, Bernoud-Hubac N et al. 2012 Oil composition of high-fat diet affects metabolic inflammation differently in connection with endotoxin receptors in mice. American Journal of Physiology. Endocrinology and Metabolism 302 E374-E386. (doi:10.1152/ ajpendo.00314.2011)

Lehr HA, Sagban TA, Ihling C, Zähringer U, Hungerer KD, Blumrich M, Reifenberg K \& Bhakdi S 2001 Immunopathogenesis of atherosclerosis: endotoxin accelerates atherosclerosis in rabbits on hypercholesterolemic diet. Circulation 104 914-920.

Levels JH, Abraham PR, van den Ende A \& van Deventer SJ 2001 Distribution and kinetics of lipoprotein-bound endotoxin. Infection and Immunity 69 2821-2828. (doi:10.1128/IAI.69.5.2821-2828.2001)

Li Z, Yang S, Lin H, Huang J, Watkins PA, Moser AB, Desimone C, Song XY \& Diehl AM 2003 Probiotics and antibodies to TNF inhibit inflammatory activity and improve nonalcoholic fatty liver disease. Hepatology 37 343-350. (doi:10.1053/jhep.2003.50048)
Lourenco AP, Vasques-Novoa F, Fontoura D, Bras-Silva C, Roncon-Albuquerque R Jr \& Leite-Moreira AF 2011 A western-type diet attenuates pulmonary hypertension with heart failure and cardiac cachexia in rats. Journal of Nutrition 141 1954-1960. (doi:10.3945/ jn.111.145763)

Lu YC, Yeh WC \& Ohashi PS 2008 LPS/TLR4 signal transduction pathway. Cytokine 42 145-151. (doi:10.1016/i.cyto.2008.01.006)

Maher JJ, Leon P \& Ryan JC 2008 Beyond insulin resistance: innate immunity in nonalcoholic steatohepatitis. Hepatology 48 670-678. (doi:10.1002/hep.22399)

Manco M, Putignani L \& Bottazzo GF 2010 Gut microbiota, lipopolysaccharides, and innate immunity in the pathogenesis of obesity and cardiovascular risk. Endocrine Reviews 31 817-844. (doi:10.1210/er. 2009-0030)

Mani V, Hollis JH \& Gabler NK 2013 Dietary oil composition differentially modulates intestinal endotoxin transport and postprandial endotoxemia. Nutrition and Metabolism 10 6. (doi:10.1186/1743-7075-10-6)

McIntyre CW, Harrison LE, Eldehni MT, Jefferies HJ, Szeto CC, John SG, Sigrist MK, Burton JO, Hothi D, Korsheed S et al. 2011 Circulating endotoxemia: a novel factor in systemic inflammation and cardiovascular disease in chronic kidney disease. Clinical Journal of the American Society of Nephrology 6 133-141. (doi:10.2215/CJN.04610510)

Medzhitov R 2001 Toll-like receptors and innate immunity. Nature Reviews. Immunology 1 135-145. (doi:10.1038/35100529)

Membrez M, Blancher F, Jaquet M, Bibiloni R, Cani PD, Burcelin RG, Corthesy I, Mace K \& Chou CJ 2008 Gut microbiota modulation with norfloxacin and ampicillin enhances glucose tolerance in mice. FASEB Journal 22 2416-2426. (doi:10.1096/fj.07-102723)

Mencin A, Kluwe J \& Schwabe RF 2009 Toll-like receptors as targets in chronic liver diseases. Gut $\mathbf{5 8}$ 704-720. (doi:10.1136/gut.2008.156307)

Michelsen KS, Wong MH, Shah PK, Zhang W, Yano J, Doherty TM, Akira S, Rajavashisth TB \& Arditi M 2004 Lack of Toll-like receptor 4 or myeloid differentiation factor 88 reduces atherosclerosis and alters plaque phenotype in mice deficient in apolipoprotein E. PNAS 101 10679-10684. (doi:10.1073/pnas.0403249101)

Miele L, Valenza V, La Torre G, Montalto M, Cammarota G, Ricci R, Masciana R, Forgione A, Gabrieli ML, Perotti G et al. 2009 Increased intestinal permeability and tight junction alterations in nonalcoholic fatty liver disease. Hepatology 49 1877-1887. (doi:10.1002/hep.22848)

Miller MA, McTernan PG, Harte AL, Silva NF, Strazzullo P, Alberti KG, Kumar S \& Cappuccio FP 2009a Ethnic and sex differences in circulating endotoxin levels: a novel marker of atherosclerotic and cardiovascular risk in a British multi-ethnic population. Atherosclerosis 203 494-502. (doi:10.1016/j.atherosclerosis.2008.06.018)

Miller YI, Choi SH, Fang L \& Harkewicz R 2009b Toll-like receptor-4 and lipoprotein accumulation in macrophages. Trends in Cardiovascular Medicine 19 227-232. (doi:10.1016/j.tcm.2010.02.001)

Munford RS \& Hall CL 1986 Detoxification of bacterial lipopolysaccharides (endotoxins) by a human neutrophil enzyme. Science 234 203-205. (doi:10.1126/science.3529396)

Nagai Y, Akashi S, Nagafuku M, Ogata M, Iwakura Y, Akira S, Kitamura T, Kosugi A, Kimoto M \& Miyake K 2002 Essential role of MD-2 in LPS responsiveness and TLR4 distribution. Nature Immunology 3 667-672.

Neal MD, Leaphart C, Levy R, Prince J, Billiar TR, Watkins S, Li J, Cetin S, Ford H, Schreiber A et al. 2006 Enterocyte TLR4 mediates phagocytosis and translocation of bacteria across the intestinal barrier. Journal of Immunology 176 3070-3079.

Netea MG, Hijmans A, van Wissen S, Smilde TJ, Trip MD, Kullberg BJ, de Boo T, Van der Meer JW, Kastelein JJ \& Stalenhoef AF 2004 Toll-like receptor-4 Asp299Gly polymorphism does not influence progression of atherosclerosis in patients with familial hypercholesterolaemia. European Journal of Clinical Investigation 34 94-99. (doi:10.1111/j.13652362.2004.01303.x)

Neves AL, Mohammedi K, Emery N, Roussel R, Fumeron F, Marre M \& Velho G 2012 Allelic variations in superoxide dismutase-1 (SOD1) gene and renal and cardiovascular morbidity and mortality in type 2 diabetic 
subjects. Molecular Genetics and Metabolism 106 359-365. (doi:10.1016/ j.ymgme.2012.04.023)

Niebauer J, Volk HD, Kemp M, Dominguez M, Schumann RR, Rauchhaus M, Poole-Wilson PA, Coats AJ \& Anker SD 1999 Endotoxin and immune activation in chronic heart failure: a prospective cohort study. Lancet 353 1838-1842.

Otaki M 1994 Surgical treatment of patients with cardiac cachexia. An analysis of factors affecting operative mortality. Chest 105 1347-1351. (doi:10.1378/chest.105.5.1347)

Pádua F, Murjal L \& Machado I 2002 In The portuguese health situation in comparison with other european countries (EU 15). Lisbon, Portugal: National Institute of Preventive Cardiology.

Pajkrt D, Doran JE, Koster F, Lerch PG, Arnet B, van der Poll T, ten Cate JW \& van Deventer SJ 1996 Antiinflammatory effects of reconstituted highdensity lipoprotein during human endotoxemia. Journal of Experimental Medicine 184 1601-1608. (doi:10.1084/jem.184.5.1601)

Parker LC, Prince LR \& Sabroe I 2007 Translational mini-review series on Toll-like receptors: networks regulated by Toll-like receptors mediate innate and adaptive immunity. Clinical Experimental Immunology $\mathbf{1 4 7}$ 199-207. (doi:10.1111/j.1365-2249.2006.03203.x)

Philpott DJ \& Girardin SE 2004 The role of Toll-like receptors and Nod proteins in bacterial infection. Molecular Immunology 41 1099-1108. (doi:10.1016/j.molimm.2004.06.012)

Pirlich M, Norman K, Lochs H \& Bauditz J 2006 Role of intestinal function in cachexia. Current Opinion in Clinical Nutrition and Metabolic Care 9 603-606. (doi:10.1097/01.mco.0000241671.09676.d8)

Poirier P \& Eckel RH 2002 Obesity and cardiovascular disease. Current Atherosclerosis Reports 4 448-453. (doi:10.1007/s11883-002-0049-8)

Puppa MJ, White JP, Sato S, Cairns M, Baynes JW \& Carson JA 2011 Gut barrier dysfunction in the Apc(Min/+) mouse model of colon cancer cachexia. Biochimica et Biophysica Acta 1812 1601-1606. (doi:10.1016/ j.bbadis.2011.08.010)

Raetzsch CF, Brooks NL, Alderman JM, Moore KS, Hosick PA, Klebanov S Akira S, Bear JE, Baldwin AS, Mackman N et al. 2009 Lipopolysaccharide inhibition of glucose production through the Toll-like receptor-4, myeloid differentiation factor 88 , and nuclear factor kappa b pathway. Hepatology 50 592-600. (doi:10.1002/hep.22999)

Read TE, Harris HW, Grunfeld C, Feingold KR, Kane JP \& Rapp JH 1993 The protective effect of serum lipoproteins against bacterial lipopolysaccharide. European Heart Journal 14 (Suppl K) 125-129.

Roncon-Albuquerque R Jr, Moreira-Rodrigues M, Faria B, Ferreira AP Cerqueira C, Lourenco AP, Pestana M, von Hafe P \& Leite-Moreira AF 2008 Attenuation of the cardiovascular and metabolic complications of obesity in CD14 knockout mice. Life Sciences 83 502-510. (doi:10.1016/ j.1fs.2008.07.021)

Sanz Y, Santacruz A \& De Palma G 2008 Insights into the roles of gut microbes in obesity. Interdisciplinary Perspectives on Infectious Diseases 2008 829101. (doi:10.1155/2008/829101)

Schreiber S 2006 Slipping the barrier: how variants in CARD15 could alter permeability of the intestinal wall and population health. Gut $\mathbf{5 5}$ 308-309. (doi:10.1136/gut.2005.076075)
Shen Y, Sultana C, Arditi M, Kim KS \& Kalra VK 1998 Endotoxin-induced migration of monocytes and PECAM-1 phosphorylation are abrogated by PAF receptor antagonists. American Journal of Physiology 275 E479-E486.

Song MJ, Kim KH, Yoon JM \& Kim JB 2006 Activation of Toll-like receptor 4 is associated with insulin resistance in adipocytes. Biochemical and Biophysical Research Communications 346 739-745. (doi:10.1016/j.bbrc. 2006.05.170)

Stoll LL, Denning GM \& Weintraub NL 2004 Potential role of endotoxin as a proinflammatory mediator of atherosclerosis. Arteriosclerosis Thrombosis, and Vascular Biology 24 2227-2236. (doi:10.1161/01.ATV. 0000147534.69062.dc)

Suganami T, Tanimoto-Koyama K, Nishida J, Itoh M, Yuan X, Mizuarai S, Kotani H, Yamaoka S, Miyake K, Aoe S et al. 2007 Role of the Toll-like receptor 4/NF-kappaB pathway in saturated fatty acid-induced inflammatory changes in the interaction between adipocytes and macrophages. Arteriosclerosis, Thrombosis, and Vascular Biology 27 84-91. (doi:10.1161/01.ATV.0000251608.09329.9a)

Tang WH, Wang Z, Levison BS, Koeth RA, Britt EB, Fu X, Wu Y \& Hazen SL 2013 Intestinal microbial metabolism of phosphatidylcholine and cardiovascular risk. New England Journal of Medicine 368 1575-1584. (doi:10.1056/NEJMoa1109400)

Tsan MF, Clark RN, Goyert SM \& White JE 2001 Induction of TNF- $\alpha$ and MnSOD by endotoxin: role of membrane CD14 and Toll-like receptor-4. American Journal of Physiology. Cell Physiology 280 C1422-C1430.

Turnbaugh PJ, Ley RE, Hamady M, Fraser-Liggett CM, Knight R \& Gordon JI 2007 The human microbiome project. Nature 449 804-810. (doi:10.1038/nature06244)

Velasquez OR, Henninger K, Fowler M, Tso P \& Crissinger KD 1993 Oleic acid-induced mucosal injury in developing piglet intestine. American Journal of Physiology 264 G576-G582.

Weisberg SP, McCann D, Desai M, Rosenbaum M, Leibel RL \& Ferrante AW Jr 2003 Obesity is associated with macrophage accumulation in adipose tissue. Journal of Clinical Investigation 112 1796-1808.

Werner T \& Haller D 2007 Intestinal epithelial cell signalling and chronic inflammation: from the proteome to specific molecular mechanisms. Mutation Research 622 42-57. (doi:10.1016/j.mrfmmm.2007.05.010)

WHO 2002 The World Health Report 2002: Reducing Risks, Promoting Healthy Life. WHO.

Wiedermann CJ, Kiechl S, Dunzendorfer S, Schratzberger P, Egger G, Oberhollenzer F \& Willeit J 1999 Association of endotoxemia with carotid atherosclerosis and cardiovascular disease: prospective results from the Bruneck Study. Journal of the American College of Cardiology 34 1975-1981. (doi:10.1016/S0735-1097(99)00448-9)

Wiesner P, Choi SH, Almazan F, Benner C, Huang W, Diehl CJ, Gonen A, Butler S, Witztum JL, Glass CK et al. 2010 Low doses of lipopolysaccharide and minimally oxidized low-density lipoprotein cooperatively activate macrophages via nuclear factor kappa B and activator protein-1: possible mechanism for acceleration of atherosclerosis by subclinical endotoxemia. Circulation Research 107 56-65. (doi:10.1161/ CIRCRESAHA.110.218420)

Received in final form 23 July 2013

Accepted 12 August 2013

Accepted Preprint published online 12 August 2013 http://jme.endocrinology-journals.org DOI: 10.1530/JME-13-0079
(C) 2013 Society for Endocrinology Printed in Great Britain
Published by Bioscientifica Ltd 